\title{
Die makrososiale ruimte van die
}

\section{Boek van die Wagte (1 Henog 1-36)}

\author{
P M Venter \\ Departement Ou-Testamentiese Wetenskap \\ Universiteit van Pretoria
}

\begin{abstract}
The macro social space of the Book of the Watchers (1 Enoch 1-36)

An analysis of the material of the Book of the Watchers (1 Enoch 1-36) indicates a preference for the spatial aspect in these revelation narratives. In an attempt to understand this preference, an investigation is launched into the macro social world of the narratives. Themes in Enoch from literature in the Bible, the SyroPhoenician world, Pseudo Epolemus, Zenon Papyri, Persia and Greece, are identified. Ptolemean Palestine is also investigated as the context within which an Enochic tradition was formed. Amongst other traditions an opposing Mosaic Judaism and Enochic Judaism are identified. Both take up the challenges of the third century with its Hellenistic onslaught and explosion of knowledge. The Book of the Watchers represents an Enoch tradition, which forms an early trajectory of apocalyptic thinking, and which is being influenced by various traditions such as wisdom literature in its mantic form, cosmological schemes of the world, and mythic traditions.
\end{abstract}

\section{INLEIDING: TIPERING VAN 'N TRAJEK VAN APOKALIP- TIESE DENKE}

Etiopiese Henog is 'n pseudepigrafiese werk wat uit ses gedeeltes of "boeke" bestaan. Hierdie gedeeltes is met verdrag bymekaar gesit om uiteindelik die boek te vorm soos dit vandag bekend is. Die Boek van die Hemelliggame (1 Henog 72-82) word oor die 
algemeen as die oudste deel beskou ${ }^{1}$. Die Boek van die Wagte (1 Henog 1-36) is die tweede oudste deel. Dit kom uit 'n ietwat latere tyd in die derde eeu vC. Vanweë die opvallende ooreenkoms tussen Genesis 6 en 1 Henog 6-11, het hierdie deel besonder baie aandag in die navorsing geniet.

In 'n vorige ondersoek (Venter 2000:38-62) het ek aandag gegee aan die drie reisverhale van 1 Henog 12-36. Hierdie verhale het nie dieselfde hoeveelheid aandag in die navorsing gekry as hoofstukke ses tot elf nie. Die twee aardse reise in 1 Henog 17-36 het op hulle beurt weer nog minder aandag gekry as die hemelse reis in 1 Henog 12-17. Ek het vanuit ' $n$ narratiewe analise van die funksie van ruimte in hierdie drie reisverhale uitgewys hoe ruimte in die verhale gebruik word om 'n bepaalde tipe orde aan te dui. Sommige plekke op aarde is geallokeer om die oortreders te huisves in afwagting op die finale oordeel. Ander ruimtes is weer die plekke waar hulle woon wat getrou is aan God.

Die drie verhale is apokalipse waarin daar opsigtelik voorkeur gegee word aan die spatiële. Dit moet op een of ander wyse korreleer met die apokaliptiese denke gedurende die derde eeu $\mathrm{vC}$ waarin dit geskep is. Dit kan ook bes moontlik iets reflekteer van die geografiese kennis van daardie tyd en die ideologiese siening van ruimte. Ek het uitgewys dat wysheid met sy kosmiese begrip van orde saam met die konsep van heiligheid en reinheid 'n rol kon gespeel het in hierdie formulering van apokaliptiese denke wat by voorkeur in terme van ruimte geskied. Om hierdie bewering te substansieer is ' $n$ verdere ondersoek nodig na die makrososiale ruimte van die vertellings. Die manier om daar te probeer uitkom is om vanuit die navorsing na die teks en sy ontstaan te gaan kyk na kontemporêre tekste wat moontlik invloed op die vorming van die verhale en die eventuele Boek van die Wagte uitgeoefen het. Uit hierdie intertekstuele navorsing kan dan iets meer duidelik word oor die sosio-historiese konteks van hierdie soort apokaliptiese teks. Dit kan daartoe bydra om die Boek van die Wagte beter te verstaan, en iets meer te begryp van die trajek van apokaliptiek wat dit verteenwoordig.

\footnotetext{
1 VanderKam (2001:91) dateer die Boek van die Wagte in die derde eeu vC op grond van die Aramese afskrifte daarvan wat by Qumran gevind is en uit die tyd van 200 tot $150 \mathrm{vC}$ kom.
} 


\section{DIE ONTSTAAN VAN DIE BOEK VAN DIE WAGTE EN DIE ROL VAN ANDER LITERATUUR}

\subsection{Die reisverhale}

Die twee aardse reise van Henog na verafgeleë en wonderlike plekke in 1 Henog 17-36 het nie opvallende ooreenkoms met die res van die Boek van die Wagte (1 Henog 1-36) nie. Volgens Stone (1984:401) verbind hoofstuk 19 wel die eerste reis (1 Henog 17:119:3) aan die voorafgaande hemelse reis (1 Henog 12-16). Hoofstuk 21 verbind ook die tweede aardse reis (1 Henog 20:1-36:4) aan die hemelse reis, maar op 'n ietwat kunsmatige manier. Die onderlinge verbinding van die drie reisverhale het vir Stone (1984:401) met die aard van die materiaal in die gedeelte te doen: "Most of the material in these chapters is 'speculative' - not totally subordinated to major eschatological themes (although such are present) and not explained by the Watchers legend." Hierdie spekulatiewe aard van die materiaal het vir Stone te doen met bepaalde beskouings wat in omloop was oor die persoon van Henog. Dieselfde soort spekulasies kom ook voor in ander Joodse materiaal soos Jubileë en Jesus ben Sirag.

Adele Yarbro Collins (1996) het die gebruik van getalle in apokalipse, soos die Boek van die Wagte, die Boek van die Hemelliggame (1 Henog 72-82) en die Hemelvaart van Moses, ondersoek. Sy kom tot die gevolgtrekking dat getalle hierin gebruik word om betekenisvolle patrone aan te dui: "Numerical symbolism in apocalyptic and related literature creates the impression of order in the physical world and in human experience. Numbers are used to order experience in two basic ways, to discover order in time and in the cosmos" (Collins 1996:135). Op die vlak van tyd word getalle nie soseer gebruik om datums te bereken nie, maar eerder om "... a meaningful pattern in time" (Collins 1996:83) aan te dui. Wanneer dit by getalle as aanduiding van kosmiese orde kom, word dit op verskillende terreine betrek. Sommige tekste werk met “.... space, with physical reality viewed as an orderly whole, a macrocosmos" (Collins 1996:90). Ander tekste werk met hemelse wesens wat geassosieer word met orde in die fisiese werklikheid. In ander tekste word die idee gereflekteer van menslike wesens as 'n mikrokosmos. In die geval van die Boek van die Wagte en die Boek van Hemelliggame “.... there is marked interest in the topography of various regions of the cosmos, especially heaven and the 
ends of the earth. In these works physical reality is ordered in certain recurring numerical patterns" (Collins 1996:99-100). In die derde deel van die Boek van die Wagte (1 Henog 12-36) word orde in die kosmiese ruimte deurgaans veronderstel. Die syfers drie, vier en sewe word telkens gebruik om die kosmiese orde aan te dui. Veral die getal sewe dui vir Collins op 'n Babiloniese en Hellenistiese agtergrond waar die getal sewe 'n belangrike rol in hulle sterrekunde gespeel het. Die filosofie van Aristobulus, dat alles in die heelal volgens die prinsipe van sewes werk, is vir haar 'n aanvaarbare verklaring vir die gebruik van die getal sewe om die orde in die kosmos aan te dui.

In my vorige narratologiese ondersoek (Venter 2000:38-62) het ek die funksionele uitbeelding van vertelruimte in die drie reisverhale ontleed. Die uitbeelding van ruimte is deurgaans ontologiese proposisies. Dit is ruimtes wat in die verhale geskep is om die aardse ruimtes te kommentarieer en daaraan 'n ideologiese waarde toe te ken wat die "verborge waarheid" daarvan bekend maak (kyk Venter 2000:44). Die verteller(s) gebruik elk keer ruimtelikheid om sy bepaalde apokaliptiese ideologie te vertel. Die apokaliptiese siening wat in die verhaal aangebied word, is dat die ganse kosmos vasgevang sit in die dualistiese stryd tussen God en sy teenstanders, die hede en die toekoms, die hemel en die aarde, die goed en die kwaad. Hierdie binêre plasing reflekteer enersyds die gangbare kultiese beskouing in Israel oor rein en onrein en andersyds die wysheidsgedagte van kosmiese orde en die bedreiging daarvan.

Die vraag kan gevra wat die agtergrond is van verwysings na plekke soos Dan suidwes van Hermon (1 Henog 13:7), Jerusalem (implisiet), of onbekende plekke soos Lesja'el tussen Libanon en Sanser (1 Henog 13:9). Is dit geografiese verwysings na letterlike plekke en niks meer nie? Hoewel Milik (1976) wel so dink, is Rowland 'n ander mening toegedaan. Daar is te veel plekke waarvoor nie 'n naam gegee word nie en waarvoor "....normal perception of the universe would not be able to give any information" (Rowland 1982:124). Die ruimtes wat hier aangedui word, is eerder ".... for religious reasons" (Rowland 1982:124) wat “... eschatological significance" (Rowland 1982:125) het. In sy ondersoek na 1 Henog 12-16 (Henog se hemelreis) verbind Nickelsburg (1984:93) die ruimte in die verhaal aan 'n letterlike geografiese plek van waar daar 'n noordelike tradisie kom: "The portrayal here of the watchers as disobedient priests from the heavenly temple suggests that this author has a complaint 
against the Jerusalem priesthood, and the setting of the story in upper Galilee near the ancient shrine of Dan may reflect the actual geographical place of origin of this tradition" (Nickelsburg 1984:93). Maar die kosmologiese materiaal in hierdie dele is telkens funksioneel verbind aan die eskatologiese hooftema daarvan: “.... cosmology undergirds eschatology" (Nickelsburg 1991:97).

\subsection{Henog 6-19}

Carol A Newsom (1980) het 'n redaksiehistoriese werkwyse gevolg in haar ondersoek na die verband tussen die vertelling oor die wagte (1 Henog 6-11) en die hemelreis van Henog (1 Henog 12-16) en ook sy eerste aardse reis (1 Henog 17-19). Die drie gedeeltes verklaar volgens haar die verhouding tussen spekulatiewe wysheid en die verskillende aspekte van apokaliptiese denke.

Die sonde van die wagte en hulle oordeel in 6-11 is "a complex but selfcontained literary unit, originally independent of the Enochic tradition" (Newsom 1980:312). Dit was 'n selfstandige eenheid wat op sy beurt redaksie-histories uit verskillende tradisies gegroei het. Daar is 'n Sjemihaza-tradisie wat met 'n Asaseltradisie aangevul is om die Wagte se verbintenis met die aardse vrouens en die gevolge daarvan uit te beeld.

Henog word vir die eerste keer in 1 Henog 12-16 by die naam genoem ${ }^{2}$. Van hier af het ons volgens Newsom met die eintlike Henogtradisie te doen. Dit is waarna Stone hier bo verwys het as spekulasies wat in omloop was oor die persoon van Henog. Die reisverhale van die Henogtradisie is redaksioneel aan die verhaal van die wagte in 6-11 gelas. In albei dele "... the problem of evil and suffering on earth is explored through speculative wisdom" (Newsom 1980:316). Daar is egter die groot verskil dat in 12-16 "... the problem of evil is perceived as a rupture in the order of the universe, a typical Enochic approach" (Newsom 1980:316). Die klem op kosmiese orde, dit wil sê konseptering in ruimtelike sin, is tipies van hierdie Henogtradisie. Dit laat Newsom (1980:313) die vraag vra oor die aard van apokaliptiek wat daarna nog dikwels in die navorsing sou opduik: ".... whether eschatology is to be deemed the central perspective of all apocalyptic literature". Daar word dikwels meer van die aspek van tyd gemaak as van

\footnotetext{
${ }^{2}$ In Henog 10:1 word daar wel na hom verwys, maar dan slegs as "die seun van Lameg".
} 
die aspek van ruimte in apokaliptiese literatuur. Met die oog op Henog se hemelreis in 1 Henog 12-16 merk Newsom (1980:316) op: "Despite the reference to 'the day of consumption' in 16:1, eschatology appears to be only one aspect (and certainly not the major one) in the resolution of the problem" (Newsom 1980:316).

Die eerste aardse reis wat Henog onderneem (1 Henog 17-19), kombineer kosmologiese spekulasie en apokaliptiese oordeel. Waar Charles (1964) en Milik (1976) in hulle kommentare die reis as vreemd aan die voorafgaande dele gesien het en Grelot (1958) dit vanuit die Mesopotamiese agtergrond as kosmiese geografie probeer verklaar het, koppel Newsom (1980) dit intertekstueel aan die praktyk van ou Naby-Oosterse diplomasie waar die koning aan sy gaste alles wys waaroor hy beskik (vgl 2 Kon 20:13). Nie net spekulatiewe wysheid nie, maar ook koninklike wysheid speel hier op apokaliptiek in om met ruimtelike konseptering 'n openbaring te gee: "Combining cosmic motifs from the speculative wisdom tradition in a narrative schema drawn from royal wisdom and ancient Near Eastern diplomacy, 1 Enoch confirms the sure sovereignty of God" (Newsom 1980: 329).

Die aardse ruimtes het dus ideologiese waarde. Die reis na die eindes van die aarde ".... is an actual journey through those cosmic expressions of God's power which wisdom speculation declared to be beyond the ken of man" (Newsom 1980:328). Hierdie gedeelte word redaksioneel doelbewus aan die vorige gedeeltes verbind om Henog se kennis van die hemelse misteries direk teenoor die geheime wat die Wagte op aarde bekend gemaak het (die gebruik van vuur en hoe om wapens te maak) te plaas. "The mysteries of the Watchers produce evil on earth, but Enoch's are in some way associated with salvation."

\subsection{Die deel oor die wagte (1 Henog 6-11)}

Redaksie-historiese navorsing gedurende die sewentiger en tagtigerjare het die vertelling oor die wagte in 1 Henog 6-11 deurgaans as 'n gelaagde komposisie hanteer. Nickelsburg (1977 en 1984) en Newsom (1980) onderskei twee strata, terwyl Hanson (1977) ten minste drie tradisielae daarin aanwys. Behalwe 'n oorspronklike Sjemihazaen Asasellaag, onderskei Hanson 'n derde stratum in 8:1-2,3; 7:16; 9:6,8c en 10:7d-8. Dit gaan terug op die mitiese tema van die kultuurheld. Hanson (1977:202) bestempel 
die Sjemihaza-verhaal as "an expository narrative" en die Asasel gedeelte in 10:4-8 as ".... an expository elaboration which sought to deepen the meaning of the Semihazah story by relating it to the yom kippur in Lev 16" (Hanson 1977:224). Nickelsburg (1984:89) sê die redakteurs van 1 Henog 6-11 "conflate at least two mythic traditions about the angelic origins of sin and God's punishment of this rebellion."

\section{$2.4 \quad 1$ Henog 1-5}

In die eerste deel van die Boek van die Wagte word die ordelikheid van die wêreld beklemtoon. Die omwentelings van die hemelliggame en die gereelde opvolging van seisoene is voorbeelde van hoe die elemente van die fisiese werklikheid konformeer aan God se bevele. Die tema van orde is hier opvallend.

\subsection{Twee fokuspunte}

Uit hierdie kursoriese aanduiding wat in die navorsing met die Boek van die Wagte gemaak word, is dit duidelik dat kosmologiese en spekulatiewe wysheid ingespan is om aan kosmiese ruimtes ideologies betekenis te gee. Twee sake is opvallend. Die eerste is dat die inhoud van die Boek van die Wagte staat maak op literatuur wat reeds bestaan. Materiaal wat deel is van die Bybelse tradisie sowel as materiaal wat los daarvan staan, het hierdie materiaal beïnvloed. Die tweede saak is dat hierdie materiaal verskillende tradisies verteenwoordig wat naas mekaar gestaan het en mekaar wedersyds beïnvloed het. Daar was 'n Henogtradisie wat uit verskillende ander tradisies gegroei het en 'n selfstandige posisie naas hulle ingeneem het.

\section{DIE INVLOED VAN ANDER LITERATUUR}

\subsection{Bybelse materiaal}

Die Sjemihaza-laag is volgens Nickelsburg 'n uitbreiding op dele van Genesis 6-9 (vgl Nickelsburg 1984: 91). Bybelse parallelle kom vir Nickelsburg (vgl 1977:392) voor in die apokaliptiese materiaal van Tritojesaja en selfs Daniël 10-12. Die Asasel materiaal in 6-11 vorm 'n tweede redaksielaag waarin bepaalde vorms van die kwaad aan 'n opstand onder die engele gewy word. Asasel het die mense metallurgie en mynbou geleer en dit 
is die basis vir al die kwaad wat daar in die wêreld is. Volgens Nickelsburg dui die verwerking van metaal op krygsaktiwiteite. Hoewel daar vir hom raaklyne met Genesis 4:22-24 is en met Tubal Kain wat daar as verwerker van brons en yster voorwerpe optree, is die naaste parallel eerder in die Griekse mitologie, in die Prometheus mite te vind (vgl Nickelsburg 1984:92).

\subsection{Die Siro-Fenisiese literatuur}

In sy diskussie op 14 April 2002 met Russel Gmirkin oor die Henogtradisie, neem David Suter $^{3}$ die standpunt in dat die bewys van 'n Henogtradisie afhanklik is van die moontlikheid om 'n literêre beweging te identifiseer wat die belange van skrywers (scribes) op die hart gedra het en wat reeds voor die Hellenistiese hervormings van die derde eeu vC oop gestaan het vir Hellenistiese kulturele invloede en praktyke in Fenisië en Sirië.

Verskillende navorsers het die Boek van die Wagte, en veral die gedeelte oor die wagte in 1 Henog 6-11, met literatuur uit die Siro-Fenesiese gebied in verband gebring. Ons het reeds gesien dat Nickelsburg (1984:93) die Henogtradisie aan die ou heiligdom by Dan in Bo-Galilea verbind het ${ }^{4}$. Die heiligdom by Dan het in die Persiese tyd in onbruik verval, maar is weer vroeg in die derde eeu $\mathrm{vC}$ onder Ptolemeus II opgeknap en weer in gebruik geneem. In aansluiting by Nickelsburg is Suter baie stellig oor noordelike invloed op die Boek van die Wagte. In sy skrywe aan Gmirkin op 14 April 2002 verklaar hy dat bereid is om daarvoor in te staan dat die name en aanspreekvorms, saam met die bepaalde tipe kosmologie wat in die Boek van die Wagte gebruik word, ooreenstem met die manier waarop Ba'al Sjamin in Sirië en Fenisië aanbid word. Hy is in die ontwikkelende monoteïsme van die streek 'n hemelgod wat toenemend met die son, maan en sterre in verband gebring word. Die titels en teologie van Ba'al Sjamin pas ook netjies in by die noordelike verwysings van Dan en Hermon waarop Nickelsburg in die Boek van die Wagte gewys het.

\footnotetext{
${ }^{3}$ Die argiewe van die diskussies wat in die 'OTPseud List' op e-pos gevoer is onder die vaandel van die 'Old Testament Pseudepigrapha Web Page' van die 'Divinity School of the University of St Andrews' onder leiding van dr David Davila, is op internet beskikbaar by Majordomo@st-andrews.ac.uk.

${ }^{4}$ Nickelsburg het hierdie teorie reeds in 1981 ontwikkel.
} 


\subsection{Pseudo-Eupolemus}

'n Geskrif uit die derde eeu vC, afkomstig uit die noordelike streke, wat volgens sommige ' $\mathrm{n}$ rol gespeel het in die Boek van die Wagte, is Pseudo-Epolemus. Attridge (1984:165-6) beskou Pseudo-Eupolemus as 'n werk van Samaritaanse oorsprong wat nog nie kennis dra van die verwoesting van die tempel op die berg Gerisim deur Johannes Hircanus in $129 \mathrm{vC}$ nie 5 . Abraham word hier in die eerste en langer gedeelte na aanleiding van Genesis 14 aangedui as die persoon wat astrologie uitgevind het en die "Galdese wetenskap" later oorgedra het aan die Fenisiërs en Egiptenaars. Aan die einde word Henog uitgewys as die eintlike een wat astrologie ontdek het. In die tweede en korter fragment van die geskrif word genoem dat Abraham sy afkoms terug herlei na die reuse. Die fragmente reflekteer 'n bepaalde openheid vir die Hellenistiese omgewing wat kenmerkend was van die Samaritane in hierdie tydperk.

Russel Gmirkin ${ }^{6}$ in sy bydrae tot die "OTPseud" diskussiegroep op 10 Maart kyk na Pseudo-Eupolemus vanuit die mamzer ${ }^{7}$-terminologie. Volgens hom put hierdie werk uit die Bybelse tradisies en ook uit die Boek van die Hemelliggame (1 Henog 72-82). Dit is dus ná hierdie boek geskryf, maar weer vóór die Boek van die Wagte. Gmirkin sien die Boek van die Wagte as 'n reaksie op Pseudo-Eupolemus. Dit is vir hom deel van 'n anti-astrologiese en anti-Samaritaanse polemiek. Dit gaan volgens Gmirkin hier eerder oor verset teen Samaritaanse astrologiese groepe as teen ander Jode. Die noordelike plekname in die Boek van die Wagte kom volgens hom net so uit Pseudo-Eupolemus.

\subsection{Die Zenon Papiri}

Zenon was 'n agent van die finansminister (dioiketes) Apollonius van Ptolemeus II Philadelphus. Hy het namens Apollonius in die gebied van Palestina gereis van Januarie 259 tot ongeveer ${ }^{8}$ April 258. Hy het van die Toring van Strato by die kus deur Jerusalem en Jerigo gereis na Transjordanië na die blyplek van die Joodse magnaat Tobias in

\footnotetext{
${ }^{5}$ En dus voor die tweede eeu vC geskryf is.

6 Deel van dieselfde OTPseud-diskussiegroep as David Suter hier bo.

${ }^{7}$ In rabbynse polemiek is mamzer ' $\mathrm{n}$ term wat teen die Samaritane gebruik is.

${ }^{8}$ Vgl Pestman (1980:141) vir die probleem rondom hierdie datering.
} 
Ammanitis. Van daar is hy noord deur die Hauran tot by die oorspronge van die Jordaan. Van daar is hy na die Fenisiese kus en terug na Egipte?

Zenon se latere korrespondensie met mense wat hy in Palestina besoek het sowel as kwitansies van die kruiehandel, is in die versameling opgeneem. Veertig van die 2000 dokumente gaan oor Sirië en Fenisië. Dit verskaf inligting oor die handel, administrasie, kultuur en tot beperkte mate die historiese gebeure in Palestina. Milik verbind die reise van Henog en die kruie handel (1 Henog 24-25) aan hierdie Zenon Papiri. Die inventaris van plekke wat in die Zenon Papiri opgenoem word in Pestman (1981:504) bevat egter nie een van die name wat in die Boek van die Wagte voorkom nie.

\subsection{Literatuur uit Persië en Griekeland}

P Grelot (1958) het die saak van Mesopotamiese invloed op die Boek van die Wagte sterk ondersteun. Grelot (vgl 1958:33-69) het uitgewys dat die sterrekundige en kalenderinligting in Henog die Mesoptamiese karakter van die wêreldkaart dra. Collins (1977:131-132) het 'n saak daarvoor uitgemaak dat Henog as "sage of heavenly wisdom" sterk steun op Mesopotaamse bronne.

Hanson herlei die materiaal in 1 Henog 6-11 na ouer mitologiese materiaal. Hy werk met mitologiese motiewe uit die ou Naby-Ooste wat sowel op die Griekse wêreld oorgedra is (in die Griekse legende van Prometheus) en “.... followed a parallel line of development in their native soil, appearing in canonical writings and later intertestamental works" (Hanson 1977:225). 'n Sektariese verduideliking van die kwaad in die wêreld is geskep deur Joodse temas wat uit die profetiese eskatologie van die klassieke profete kom, te gebruik en dit te laat voortleef in 1 Henog 6-11 en aanverwante komposisies "in a rather thorough metamorphosis, at the heart of which is a new perspective on divine activity, that of apocalyptic eschatology" (Hanson 1977:233). Daar loop egter 'n baie sterk eenheidslyn tussen die mitologiese materiaal en die eindproduk. "This unity is the result of the basic pattern which underlies the narrative, the archaic pattern of the rebellion-in-heaven myth. That the essential features of this myth can be traced in an unbroken continuum on near eastern soil from the mid-second millennium down to the time of the composition of the Semihazah narrative documents the vitality

\footnotetext{
${ }^{9}$ Vgl die kaart van sy reise op die ongenommerde bladsye agter in Pestman (1980).
} 
with which ancient mythic patterns of thought continued to influence the way in which thinkers of later epochs explained the basic tension which they experience in the universe" (Hanson 1977:232). Hierdie tradisie van 'n organiese tipe uitleg kom ook voor in Pseudo-Jonatan en Jubileë.

Sowel Nickelsburg (1977) as Collins (1996) is van oortuiging dat die Boek van die Wagte op 'n intensiewe interaksie tussen Hellenistiese materiaal en Joodse geskrifte dui. Nickelsburg sien in die Sjemihazaverhaal in 1 Henog 6-11 invloed van Griekse mites. Daar is parallelle met die Titanomachia en Gignatomachia, maar veral met Hesiodus se Katalogus van Vrouens en sy Eoiae. Hy sien ook in Aesgulys se verhaal oor Prometheus 'n parallel. Ook hier steel die god Prometheus vuur en leer die mense om wapens te maak. Hy word gestraf en teen 'n rots vasgemaak. Dit is vir Nickelsburg (vgl 1977:405) aanduiding dat 'n targoemis Levitikus 16 en die Henog-materiaal bymekaar gebring het en uit die Prometheus mite die motief van inperking tot 'n bepaalde plek, bygevoeg het.

Hierbo is reeds op Adele Yarbro Collins (1996) se bevinding gewys dat die gebruik van getalle om kosmiese orde in die Boek van die Wagte aan te dui wys op 'n Babiloniese en Hellenistiese agtergrond. Veral die filosofie van Aristobulus dat alles in die heelal volgens die prinsipe van sewes werk, het volgens haar 'n rol gespeel in die gedeelte van 1 Henog 34-36. Die getal sewe word ook nie gebruik in verband met die Joodse week van sewe dae of die sabbat nie, maar eerder in samehang met die Griekse filosofie. "The most immediate associations are with the Babylonian and then Hellenistic idea of the seven planets" (Collins 1996:136). Die gebruik van hierdie astrale motiewe ".... indicate the significant degree to which Jewish and Hellenistic culture have interacted in these works. Two non-apocalyptic Jewish writers, Aristobulus and Philo, show an even greater degree of compatibility between the two cultures. Their use of or response to Hellenistic ideas is much more explicit" (Collins 1996:136).

\subsection{Opsomming}

Die invloed van ander literatuur op die Boek van die Wagte is hier bo aangetoon deur op ooreenstemmende temas of idees te wys. Daar moet egter veronderstel word dat die Boek van die Wagte tot stand gekom het in 'n wêreld waarin daar baie meer invloede was 
wat daarop ingewerk het as net hierdie paar moontlike literêre verwysings. Daar was nie net kulturele invloede van buite nie, maar ook verskillende tradisies onder Joodse geledere wat onderling op mekaar ingewerk het ${ }^{10}$. Daar kan selfs in die meervoud van Judaïsmes van die derde eeu gepraat word. Met die min inligting wat daar is en die verskillende teorieë wat gehuldig word waag ek dit vervolgens om iets meer van hierdie derde eeuse Palestynse scenario te skets.

\section{PALESTINA IN DIE PTOLEMESE TYDPERK}

\subsection{Historiese buitelyne}

Aleksander het Persië in 333 vC oorwin en die Persiese ryk nog selfs verder uitgebrei. Na sy dood in $323 \mathrm{vC}$ en tot by $301 \mathrm{vC}$ was sy generaals (die Diadogi) in oorlog met mekaar betrokke oor die verdeling van sy ryk. Palestina was in die konflik tussen Ptolemeus en Seleukus van uiters strategiese belang ${ }^{11}$. Ptolemeus I Soter het Palestina in $301 \mathrm{vC}$ beset en dit het deel van die Ptolemese ryk van Egipte geword. Antiogus III die Grote het die Seleukidiese troon in $223 \mathrm{vC}$ bestyg. Hy slaag daarin om tydens die Vyfde Siriese oorlog in $200 \mathrm{vC}$ die Egiptiese generaal Scopus by Paneas in Bo-Galilea te verslaan. Vanaf 198 vC word Palestina deel van die Seleukidiese ryk. Tussen 301 en 198 vC was Judea dus onder Ptolemese beheer. Buiten die Vierde Siriese Oorlog (219-217 vC) was die tyd onder die Ptolemeërs oor die algemeen 'n tyd van vrede waarin daar geleidelike veranderinge oor die hele Palestina gekom het. Die Ptolemeërs het veral op ekonomiese gebied die septer in Palestina en Fenisië geswaai.

Egipte het Judea as deel van die gebied "Sirië en Fenisië" beskou. Dit het die gebiede van Palestina, Transjordanië, die stede van Tirus en Sidon en dele van suidelike Sirië ingesluit. Aan die hoof van die gebied het 'n strategos gestaan. Hy het die gebied onderverdeel in hyparchaiai, moontlik volgens etniese riglyne (vgl Gafni 1984:4). Judea was een van hierdie hupargieë. Dit het as politieke eenheid redelik ooreengestem met die administratiewe eenheid Jehud in die Persiese tyd. Dit het dieselfde grense gehad. Die

\footnotetext{
${ }^{10}$ Grabbe (1992:180) praat van die Boek van die Wagte as verteenwoordiger uit die laat-Ptolemese tyd van "... the thinking of one section of Palestinian Judaism for this period".

11 Hengel (1974) het die baanbrekerswerk in die navorsing na hierdie geskiedenis gedoen.
} 
noordelike grense ${ }^{12}$ was Bet-El (noord van die huidige Ramalla) en suid Bet Zur (net noord van Hebron). Oos het dit geloop tot by die Jordaan en Jerigo en wes was die vlakte van Lydda. Judea was die gebied met die hoogste konsentrasie Jode. Daar het ook Jode in die enklawe van Trans-Jordanië, bekend as die Peraea, gebly en ook in Galilea. Teen ongeveer $210 \mathrm{vC}$ het daar ook 'n Joodse militêre kolonie by Leontopolis in Egipte tot stand gekom toe die hoëpriester Onias IV na Egipte gevlug het.

Volgens Grabbe (1992:171-220) was Judea in wese 'n teokrasie onder die Perse en het so gebly in die tyd van die Ptolemeërs. Die hoëpriester was die leier van die land. Onder hom het die streek 'n mate van selfregering gehad, sowel as godsdienstige outonomiteit (as religio lecita). Van vroeg reeds is hy bygestaan deur 'n raad wat uit priesters en individue bestaan het vanuit die plaaslike aristokrasie. Wanneer presies hierdie raad (Knesset Gedola, in die Griekse bronne die gerousia) tot stand gekom het, is onbekend.

In hierdie tyd het die Tobiasfamilie ${ }^{13}$ 'n belangrike rol begin speel. Die geskiedenis van die Tobiasfamilie gaan selfs so ver terug as die tyd voor die ballingskap. Hierdie familie het 'n rol gespeel in die geskiedenis van Judea tot selfs by die Makkabese opstand. Hulle was in Transjordanië gevestig naby die Jordaan, by wat vandag bekend is as Araq el-Emir. Tobias was getroud met die suster van die hoëpriester Onias II in Jerusalem. Volgens Gafni (1984:6) het daardeur "certain new elements of a particular cultural and political orientation .... begun to infiltrate portions of the Judaean establishment." Daar het boonop twis ontstaan tussen die familie van Tobias en diè van Onias. Toe die hoëpriester Onias II in $240 \mathrm{vC}$ onwillig was om belasting aan Egipte te betaal, omdat hy as pro-Seleukied sy hoop gevestig het op 'n spoedige verandering van regeerders, het Tobias se seun Josef, sy oom se onwilligheid uitgebuit. Hy het met geld wat hy by vriende in Samaria geleen het, in Aleksandrië gaan tender vir die "tax farming rights to Palestine" (Grabbe 1992: 197) wat hy toe ook van die Ptolemeërs gekry het. Hierdeur het daar spanning tussen die twee groepe gekom.

\footnotetext{
12 Hierdie grense stem nie ooreen met die geografiese gebied wat in Henog se reisverhale (1 Henog 17-36) uitgekarteer word nie.

13 Vanderkam (2001:14) verwys na die Tobiad Romance. Grabbe (1992:217) verwys na die "semile.gendary story of the Tobiads". Sien ook Goldstein (1975:85-123). Goldstein sien die verwysing in Filo na hierdie familie as pro-Ptolemese Joodse propaganda wat deur Onias IV geskryf is.
} 
Josef se jongste seun Hircanus het in sy voetspore gevolg. Hy het onder Ptolemeus III Euergetes sy pa in die laat derde eeu as belastinggaarder van Egipte met 'n slenter vervang. Dit het struweling tussen hom en sy pa en sy broers laat ontstaan. Toe hy in $210 \mathrm{vC}$ terugkeer van Egipte moes hy uitwyk na die familie se landgoed in Transjordanië. Hy was beperk tot die Ptolemese provinsie Ammanitis en kon slegs daar belasting invorder. In hierdie proses het sy broers in Jerusalem saam met die hoëpriester Simon II die Regverdige, die seun van Onias II, hulle aan die kant van die Seleukiede teenoor die Ptolemeërs begin skaar Hircanus het tot selfs in die tyd van Antiogus Epifanes in $167 \mathrm{vC}$ 'n ondersteuner van die Ptolemeërs gebly, terwyl die Tobiasfamilie in Jerusalem saam met Simon die Seleukiede gesteun het. Teen die tyd dat Antiogus II sukses behaal in die Vyfde Siriese Oorlog van 202-200 vC is die pro-Seleukiede groep dan ook in die meerderheid in Jerusalem. Dit is vir hierdie Simon die hoëpriester ( $\mathrm{vgl}$ Hengel 1980: 38) wat Ben Sirag so vol lof is in Sirag 50:4. Hierdie interne politiek het 'n geweldige rol gespeel in die groepsvorming in Jerusalem en verklaar bes moontlik iets van die etikettering van bepaalde mense in die Boek van die Wagte.

\subsection{Hellenisme}

Die uitwerking van die Hellenisme wat Aleksander die Grote na die ou Nabye-Ooste gebring het, het eers met verdrag duidelik geword. Dit het ook nie orals dieselfde verloop nie. In Egipte ${ }^{14}$ was daar nie 'n gemengde bevolking soos by die Seleukiede wat so vatbaar was daarvoor nie. In Egipte het die priesters die ruggraat van die nasionale weerstand daarteen gevorm. Hierdie weerstand het met tyd verkrummel sodat volgens Hengel (1980:74) “....increasing advances were made by the unique type of GraecoEgyptian 'mixed culture' which became characteristic of the late Ptolemaic and Roman period, while the difference between Alexandria and Chora persisted."

Hoewel Jerusalem vanweë sy geografiese afgesonderdheid aanvanklik die druk van Hellenisme ontkom, word sy inwoners reg van die begin af in $301 \mathrm{vC}$ deur Ptolemeus I Soter en later sy seun Ptolemeus II Filadelfus ingetrek by die ekonomiese en militêre

\footnotetext{
${ }^{14}$ Grabbe (1992:166) merk op dat die verskil tussen die Ptolemeërs en Seleukiede gesien kan word in die manier waarop hulle die Joodse staat hanteer het. "The pressure to adapt to Greek ways was fairly general and diffuse under the Ptolemies. Because the Seleucids put a good deal of emphasis on Greek foundations, however, under them there was pressure to engage in more specific and more communal measures ...."
} 
uitbouings daarvan as buffersone teen die Seleukiede. Daar was sterk kontak met handelaars, soldate en administrateurs uit Egipte. Veral op die gebied van die handel het Joodse handelaars die Griekse taal begin gebruik omdat dit ekonomiese voordeel vir hulle ingehou het. Deur mense soos Tobias se seun Josef was daar ook sterk diplomatieke betrekkinge met Judea. 'n Veregiptianiseerde vorm van Hellenisme het in hierdie tyd in Palestina ingekom. Hoewel Jerusalem relatief arm was teenoor groter stede soos diè in Fenisië, was daar lewendige intellektuele aktiwiteit aan die gang. Alhoewel navorsers van mekaar verskil oor die impak van die invloed van Hellenisme, moet daar minstens toegegee word dat Hengel (1980:111-112) reg is oor die tydsgees: “.... an intellectual climate that was prepared to be stimulated and influenced in a number of ways; in particular some tendencies in the development of Jewish wisdom and also in apocalyptic .... open to ... an encounter with Greek ideas." Egipties-Hellenistiese denke het sterk invloed uitgeoefen op die Joodse denke, veral op konsepte soos kosmies bepaalde tyd en kosmiese orde wat ons in die Boek van die Wagte teenkom.

Coggins (1998:46) wys tereg daarop dat die ouer beeld van 'n radikale weerstand teen Hellenisme nou agterhaal is. Gafni (1984:4) is veel meer genuanseerd wanneer hy praat van "inroads made by the hellenizing process among certain strata of Jewish society". Almal sal seker nie met Hengel (1974) of met Stone (1978: 480) saamstem dat Hellenisme veranderings meegebring het wat selfs meer ingrypend was as die Babiloniese ballingskap nie. Grabbe (1992:168) is nader aan die kol as hy Hellenisering sien as ".... a centuries-long process in which all were engaged and from which no one escaped", maar dan verstaan dat daar verskillende grade was waarin dit mense en sake beïnvloed het. Selfs tussen die wat teen Hellenisme gekant was, was daar verskille: “... the attitudes of those called "Judaizers" seem to have covered a wide spectrum, represented by the Hasidim, the Maccabees, those who refused to defend themselves against their enemies, the partisans of Onias, and those who wrote Daniel 7-12; the same is true of the so-called Hellenizers" (Grabbe 1992:169).

Selfs die eventuele invloed op die godsdiens het eienaardige kombinasies afgegee: “... western Asia became spiritually Hellenistic even while it maintained certain local traits such as absolute monarchy and religious practices centred on the ancestral gods" (LaCocque 1988:17). Soos in Egipte het die godsdiens in Judea tradisionele sowel as 
progressiewe komponente vertoon. In dokumentering van die godsdiens van hierdie tyd in Jerusalem, soos die van Demetrius die chronograaf uit die tyd van Ptolemeus IV Filopater (225-205), of fragmente van Joods-Hellenistiese skrywers uit die Ptolemese tyd wat deur Aleksander Polyhistor, die Romein (105-49) bewaar is, kan gesien word hoe die Jerusalem tempel ook met Grieks op hoogte moes bly om as godsdienssentrum te kon bly funksioneer. So kan invloed van Griekse denke in sommige dele van Hebreeuse wysheidsliteratuur gesien word, soos byvoorbeeld Prediker wat volgens Hengel (1980:120) “ $\ldots$ an aura of the early Hellenistic enlightenment" dra.

Hierdie gebeure moet egter as 'n tendens gesien word wat teen die derde eeu maar nog aan die begin van die proses was. Eers teen die tweede eeu $\mathrm{vC}$ het die invloed van Hellenisme duideliker begin uitkristalliseer. Teen die agtergrond van hierdie geskiedenis en die groeiende invloed wat Hellenisme op die Judese godsdiens gehad het, kan daar nou aandag gegee word aan die tradisies en groepe van die derde eeu $\mathrm{vC}$, soos die Henogtradisie.

\section{GROEPE EN TRADISIESTROME}

Daar is Joodse literatuur uit die derde eeu $\mathrm{vC}$ wat nie deel geword het van die Joodse kanon nie, maar wel in Christelike kringe bewaar is, of deur argeologie herwin is. Stone (1978: 483) wys op drie redes vir die ontstaan van hierdie literatuur: eerstens interne ontwikkelinge in Judaïsme, tweedens invloede van ander kulture soos die van die Perse en Grieke en heel belangrik, derdens, ouer materiaal en idees wat nie in die hoofstroom van religieuse tradisie opgeneem was nie, maar wat nou weer na vore kom. Stone (1978:489) se gevolgtrekking is: "Among the groups of assimilationists and the pious, the wise and the Hasideans, a place must now be found for those who cultivated sacred speculation on subjects represented in the early parts of 1 Enoch". Naas die verskillende

groepe soos die meelopers met die Ptolemeërs en later die Seleukiede, die groepe wat buitelandse invloed met alle mag probeer teenwerk het, die wysheidskole, was daar ook spekulatiewe groepe onder wie die Henogtradisie uitgebou is. 


\subsection{Mosaïese Judaïsme}

Hanson het op grond van Mannheim se sosiologiese modelle van kennis ' $n$ ideologiese en utopiese mentaliteit in die post-eksiliese tyd onderskei. Die Huis van Sadok kan as 'n tipiese ideologiese komponent beskou word. Die hoëpriester Simon II die Regverdige (die seun van Onias II) was uit die huis van Sadok. Sy opvolger Onias III (c 196-174 vC) was uit dieselfde familie. Alle hoëpriesters, vanaf die inwyding van die tweede tempel in $515 \mathrm{vC}$, was uit hierdie huis. Eers in $153 \mathrm{vC}$ toe Jonatan Makkabeus uit die Makkabeërfamilie hoëpriester geword het, het sake verander. Die belange van hierdie familie het ook reeds in $210 \mathrm{vC}$ begin verskuif toe die hoëpriester Onias IV na na Egipte gevlug het en hom by Leontopolis gaan vestig het.

Gedurende die derde eeu $\mathrm{vC}$ het die Sadokiete, bekend as die Oniadiete, in alliansie met die Tobiadiete, na wie hier bo verwys is, die leiding geneem in die Knesset Gedola. Die Huis van Sadok "evolved a particular understanding of its part in God's dispensation for Israel; of a sense of its own eternal worth as the chosen high priestly dynasty; and of the profound significance of the Temple Service for which it was ultimately responsible before God" (Hayward 1996:39). Hulle het hulle bepaalde seleksie van tradisies gehad wat deur die soferim bewaar en oorgelewer is. Hierdie bepaalde versameling het hulle as norm vir die godsdiens voorgehou en dit verskans met die mag wat hulle oor die gemeenskap gehad het. Na hierdie komponent van die samelewing kan verwys word as die draers van die tradisionele Mosaïese Judaïsme.

\subsection{Die Hasidim}

Die utopiese mentaliteit het by verskillende groepe na vore gekom. In die navorsing word daar tans al te maklik van 'n Mosaïese tradisie teenoor 'n Henogitiese tradisie gepraat asof dit die enigste twee alternatiewe van die tyd was. Daar was ook groepe soos die Hasidim.

Die omstrede term Hasidim word gebruik as aanduiding van 'n hipotetiese faksie van die samelewing wat uit veral skrywers ("scribes") bestaan het. Veral LaCocque ${ }^{15}$ het die begrip gebruik met die oog op die tweede eeu waarin Daniël ontstaan het om te verwys na 'n groep wat Rowland (1982:211) sou aandui as “... a loosely defined group, possibly

15 Kyk LaCocque (1988 en 1993). 
related to the continuation of visionary activity found in some later prophetic oracles which looked to the future as the time when the promises made by God to the prophets would be realized". Hengel (1980:123) plaas hulle ontstaan egter kort voor of met die Hellenistiese hervorming. In hulle kan die gees van die nuwe tyd gesien word. Hengel (1980:124) sien hierdie groep met hulle sterk apokaliptiese stempel nie “... in conscious opposition to Jewish wisdom or to the Temple cult. In reality the division of the people ran through the priests and Levites as well as through the scribes." Dit is nie noodwendig dat die Henogtradisie uit hulle geledere kom nie, maar dit het besliste raaklyne daarmee.

\subsection{Apokaliptiek}

Die oudste Joodse apokalips (Die Boek van die Hemelliggame 1 Henog 72-82) kom uit die derde eeu vC. Hoewel daar al vantevore apokaliptiese tendense kon wees, word dit vir die eerste keer onder die Ptolemese omstandighede 'n uitkenbare tradisiestroom in Judaïsme (vgl Grabbe 1992:218). Vir Grabbe is apokaliptiek nie noodwendig die standpunt van 'n gemarginaliseerde of revolusionêre groep nie, maar 'n verwagting in die Ptolemese tyd wat nie wêreldrugbaar gemaak is nie. Daar is “... strong apocalyptic strands in Judaism at this time while ... the life of the people does not seem to have been overly agitated by such ideas" (Grabbe 1992: 219).

Davies (1989:268) maak belangrike opmerkings: "There is no one 'apocalyptic group', though a literary 'apocalyptic movement' at this time might be imagined. But we must recognize that the genre of apocalypse was not created by a situation but adapted for a situation". Vraagstukke van die tyd, soos die vraag na die oorsprong van die kwaad, die oorsprong en aard van sonde, die rol van die engele, dui alles op 'n gebrek aan morele orde in die gemeenskap en 'n religieuse krisis waarmee gestoei word. Hierdie probleme word vanuit 'n geheel eiesoortige hoek aangepak waarin kosmiese teorieë, astrologiese kennis en invloede uit ander kulture 'n groot rol speel. Wysheidstaal en -idees word gebruik om daarop aanspraak te maak om onder die bepaalde omstandighede 'n alternatief aan te bied vir die Mosaïese tradisie. 


\subsection{Wysheid}

Die debat oor die herkoms van apokaliptiek is grootliks gestimuleer deur Von Rad se standpunt dat mantiese wysheid die oorsprongpunt van apokaliptiek is. In die debat is ' $\mathrm{n}$ profetiese oorsprong met net soveel drif verdedig as die standpunt dat die wysheid die beginpunt is van apokaliptiek. Dit het in elk geval duidelik geword dat dit nie net wysheid, of profesie, of een bepaalde kultuur was wat as bron vir apokaliptiek gedien het nie, maar 'n groot verskeidenheid van invloede, soos die Persiese godsdiens, Persiese dualisme, Iranese mitologie, Hellenisme, Ptolemese kosmologie, ensovoorts. Oswalt (1999:389) neem daarom die standpunt in dat "apocalyptic thought is more of a mutation than a logical development".

Die aanwesigheid van fragmente van beide Ben Sirag en Henog by die Dooie Seerolle het 'n studie soos die van Randy Argall (1995) van ooreenkomste en verskille tussen die wysheid en die apokaliptiek gestimuleer. Ook hieruit het dit duidelik geword dat die apokalips van die Boek van die Wagte 'n aanduiding is van die wedersydse beïnvloeding van wysheid en apokaliptiek reeds in die Ptolemese tyd.

\subsection{Die Henogtradisie}

Russel Gmirkin ${ }^{16}$ kom tot die slotsom dat die Boek van die Wagte na sy vorm 'n openbaringsteks is, maar dat die belangstelling van die werk in die kosmiese opset veel wyer strek as net apokaliptiese belange. Tradisies wat in omloop was oor tempels en eskatologiese visies oor die hemel as 'n tempel waarin God bly, het 'n sterk rol gespeel in die bespiegelings in die boek. Stone (1978:491) het selfs na hierdie beskouing verwys as "proto-apocalyptic". Hy noem dit "A newly isolated and dated type of apocalyptic speculative writing containing some eschatological elements and much other material is now known from the third century" (Stone 1978:491-2). Stone (1984:391) is van oortuiging dat ons hier met apokaliptiese literatuur te doen het wat "far from exclusively or even predominantly eschatological" is. Veel eerder as eskatologiese openbaring, gaan dit hier oor die openbaring van die hemelse wêreld. Die fokuspunt getuig eerder van "a developed 'scientific' lore about astronomy, astrology, calendar and angelology" (Stone

$\overline{16}$ In sy deelname aan die diskussie van die OTPseud-groep op 10 Maart 2002. 
1984:391), 'n tyd waarin die kosmos met alles daarin die voorwerp van bespiegeling en navorsing is.

Wanneer die groep geïdentifiseer moet word, is daar sprake van 'n “.... sectarian point of view .... outside of the mainstream of temple praxis" (Hanson 1977:226). Dit is moontlik die "speculation of a sectarian apocalyptic movement of the third century BCE ...” (Hanson 1977:219). Dit kon volgens Hanson (1977:220) selfs raaklyne met die Hasidim gehad het. Stone is egter nie seker of hulle as 'n groep of sekte beskou moet word nie. Hulle verteenwoordig wel 'n "intellectual tradition" van "well educated men", "associated with the traditional intellectual groups, the wise and the priests" (Stone 1978:489). Volgens Harrison (1997:177) se analise van die tyd aan die hand van Prediker was dit 'n redelike vloeibare tyd: "In broader economic and political realms, the rise of new elites (like the Tobiads, and to a lesser extent the urban bourgeoisie) demonstrated the new order's depreciation of ascriptive status and more open channels of upward mobility."

As die groep sosiaal geplaas moet word is dit meer hulle omstandighede as enigiets anders wat 'n leidraad kan gee. Hanson (1977:219) praat van "victims of oppression find themselves powerless to eradicate the evil they see engulfing them", 'n ".... harsh indictment against the temple cult and its expository tradition, an indictment originating within the sectarian perspective of a highly developed apocalyptic eschatology" (Hanson 1977:226). Nickelsburg (1977:391) het na militêre konflik verwys: "conflict so fierce, incessant, and widespread as to lead our author to claim that the existence of the human race was threatened." Hy plaas die Boek van die Wagte so ver terug as die tyd van die Diadogi van die vierdie eeu vC. Hanson (1977:219) praat van omstandighede waarin die outeurs "give expression both to their bitter frustration and their fervent hopes by creating a new myth." Suter (2002) sluit by Nickelsburg aan in die oortuiging dat dit gaan oor korrupsie in die huwelike van priesters by die tempel in Jerusalem. Dit gaan in die Boek van die Wagte om 'n "polemic against the priesthood, based in part on technical language from the temple and priesthood applied to the sanctuary in heaven, and the substitution of Dan for Jerusalem as the point of access to the sanctuary of heaven." Hierby sluit Gmirkin aan met die verduideliking dat die 
agtergrond die Jerusalemse priesters is wat die huweliksreëls van Levitikus 21 oortree het en onreinheid oor die tempel gebring het.

\section{SAMEVATTING EN KONKLUSIE}

Die ondersoek na die makrososiale ruimte van die vertellings in die Boek van die Wagte het uitgewys dat daar veel meer op die spel was as net kosmologiese motiewe uit die spekulatiewe wysheid of die kultiese onderskeid tussen rein en onrein.

Daar was 'n klomp kontemporêre tekste uit verskillende buurkulture wat invloed op die vorming van 'n Henogtradisie en die skryf van die Boek van die Wagte uitgeoefen het. Dit is moontlik om verskillende gemeenskaplike temas of idees tussen hulle en die Boek van die Wagte uit te wys. Dit was egter ook duidelik dat daar deur hierdie literatuur nie net kulturele invloede van buite ingewerk het op die outeur(s) van die Boek van die Wagte nie, maar dat daar ook verskillende tradisies onder Joodse geledere was wat onderling op mekaar ingewerk het.

Die Ptolemese tyd was vir Judea 'n tyd van toenemende Hellenistiese beïnvloeding. Alhoewel die impak van die Hellenistiese kultuur nog nie so groot was tydens die derde eeu $\mathrm{vC}$ nie, het die politieke verbondenheid aan Egipte en die politieke intriges wat dit onder die leierkorps in Jerusalem veroorsaak het, Judea voor die uitdaging gestel waarvoor die tradisionele Mosaïese tradisie volgens sommige nie opgewasse was nie. Egipties-Hellenistiese invloed het 'n spekulatiewe gees laat ontwaak wat vanuit 'n breë spektrum van kennisvelde na eie oplossings gesoek het.

Eietydse probleme soos 'n gebrek aan morele orde in die gemeenskap en die religieuse krisis wat dit meebring, ontlok vrae oor die oorsprong en aard van die sonde, die rol van die engele en die patrone in die kosmiese orde. Die ontluikende Henogtradisie probeer antwoorde gee op hierdie vrae deur gebruik te maak van 'n potpourri van inligting uit ander literatuur, perspektiewe uit die wysheid (veral die mantiese wysheid), bestaande apokaliptiese tendense in die samelewing, en so meer. Die Henogtradisie is meer ruimtelik georiënteerd as wat dit op tyd ingestel is. Iets van Malina (1995) se vertolking van die boek Openbaringe vanuit astrologiese kennis lyk of dit ook hier van pas kan wees. Dit was egter 'n benadering wat in konkurrensie gestaan het met die Mosaïese tradisie en miskien selfs polemies gerig was teen sommige van die 
draers van daardie tradisie. Omdat die Henogtradisie nie die steun gehad het van persone in ' $n$ magsposisie in die samelewing nie, het dit sy pad gevind onder diegene wat as randfigure hulle bestaan gevoer het.

Hoewel daar iets duideliker geword het uit hierdie studie van die makro-sosiale ruimte van die Henogvertellings in die Boek van die Wagte, is daar twee terreine wat in die toekoms nog verder ondersoek moet word. Die invloed van die Egiptiese Hellenisme het in die navorsing nog nie genoeg aandag gekry nie. Die wysheid van Egipte en die toekomsverwagtings wat daar was in Egipte, is op die lange duur ook beïnvloed deur die impak van Hellenisme en op 'n eiesoortige manier verwerk. Dit moes ook bepaalde invloed op die Henogtradisie gehad het. Die ander veld van ondersoek is die sosiaalwetenskaplike ondersoek na die inhoud wat aan ruimte in 'n maatskappy gegee word. As daar gekyk word na die rol wat die besit van grond en land in die maatskappy speel, dan moet die opvatting oor kosmologiese ruimte binne die derde eeuse Naby-Oosterse milieu met sy bepaalde samestelling van groepe en tradisies ook 'n rol speel wat tot dusver nog nie genoeg bestudeer is nie.

\section{Literatuurverwysings}

Argall, R-A 1995. Reflections on 1 Enoch and Sirach: A comparative literary and conceptual analysis of the themes of revelation, creation and judgement, in Society of Biblical Literature 8, 337-351. Atlanta: Scholars Press.

Attridge, H W 1984. Historiography, in Stone, M E (ed), Jewish writings of the Second Temple Period: Apocrypha, Pseudepigrapha, Qumran Sectarian Writings, Philo, Josephus, 157-184. Philadelphia: Fortress.

Charles, R H 1964. The Book of Enoch or 1 Enoch. Hastings: Society of Metaphysicians.

Coggins, R J 1998. Sirach. Sheffield: Sheffield Academic Press.

Collins, A Y 1996. Cosmology and eschatology in Jewish and Christian apocalypticism. Leiden: Brill.

Collins, J J 1977. Cosmos and salvation: Jewish wisdom and apocalyptic in the Hellenistic age. $H R$ 17, 131-132. 
Davies, P R 1989. The social world of apocalyptic writings, in Clements, R E (ed), The world of Ancient Israel: Sociological, anthropological and political perspectives, 251-271. Cambridge: Cambridge University Press.

Gafni, I 1984. The historical background, in Stone, M E (ed), Jewish writings of the Second Temple period: Apocrypha, Pseudepigrapha, Qumran sectarian writings, Philo, Josephus, 1-31. Philadelphia : Fortress Press.

Goldstein, J A 1975. The tales of the Tobiads. Christianity, Judaism and other GrecoRoman Cults 3, 85-123.

Grabbe, L 1992. Judaism from Cyrus to Hadrian, Volume One: The Persian and Greek Periods. Minneapolis: Fortress.

Grelot, P 1958. La geographie mysthique d'Henoch et ses sources orientales. $R B$ 65, 3369.

Hanson, P D 1977. Rebellion in Heaven, Azazel and Euhemeristic Heroes in 1 Enoch 611. JBL 96(2), 195-233.

Harrison, C R 1997. Qoheleth among the sociologists. Biblical Interpretation 5(2), 160180.

Hayward, C T R 1996. The Jewish Temple: A non-biblical sourcebook. London: Routledge.

Hengel, M 1974. Judaism and Hellenism. Philadelphia: Fortress.

Hengel, M 1980. Jews, Greeks and Barbarians: Aspects of the Hellenization of Judaism in the pre-Christian Period. London: SCM.

LaCocque, A 1988. Daniel in his time. Columbia: University of South Carolina Press.

LaCocque, A 1993. The socio-spiritual formative milieu of the Daniel apocalypse, in Van der Woude, A S (ed), The Book of Daniel in the light of new findings, 318338. Leuven: Leuven University Press.

Malina, B 1995. On the genre and message of Revelation: Star visions and sky journeys. Peabody: Hendrickson.

Newsom, C A 1980. The development of 1 Enoch 6-19: Cosmology and judgement. CBQ 42(3), 310-329.

Milik, J T 1976. The Books of Enoch. Oxford: Clarendon.

Nickelsburg, G W E 1977. Apocalyptic and myth in 1 Enoch 6-11. JBL 96, 383-405. 
Nickelsburg, G W E 1981. Enoch, Levi, and Peter: Recipients of Revelation in Upper Galilee. JBL 100, 575-600.

Nickelsburg, G W E 1984. The Bible rewritten and expanded, in Stone, M E (ed), Jewish writings of the Second Temple Period: Apocrypha, Pseudepigrapha, Qumran sectarian writings, Philo, Josephus, 89-156. Philadelphia: Fortress.

Nickelsburg, G W E 1991. The apocalyptic construction of reality in 1 Enoch, in Collins J J \& Charlesworth, J H (eds), Mysteries and revelations: Apocalyptic studies since the Uppsala colloquim, 51-64. Sheffield: JSOT Press.

Oswalt, J N 1999. Recent studies in Old Testament apocalyptic, in Baker, D W \& Arnold, B T (eds), The face of Old Testament studies: A survey of contemporary approaches, 369-390. Grand Rapids, MI: Baker Books.

Pestman, P W (ed) 1980. Greek and Demotic texts from the Zenon archive (P.L.Bat. 20). Leiden: Brill. (Papyrologica Lgdono-Batava.)

Pestman, P W 1981. A Guide to the Zenon archive. (P.L.Bat. 21). Leiden: Brill. (Papyrologica Lgdono-Batava.)

Rowland, C 1982. The open heaven: A study of apocalyptic in Judaism and early Christianity. London: SPCK.

Stone, M E 1978. The Book of Enoch and Judaism in the third century BCE. CBQ 40, 479-492.

Stone, M E 1984. Apocalypic literature, in Stone, M E (ed), Jewish writings of the Second temple period: Apocrypha, Pseudepigrapha, Qumran sectarian writings, Philo, Josephus, 383-441. Philadelphia: Fortress.

Vanderkam, J C 2001. An Introduction to Early Judaism. Grand Rapids, MI: Eerdmans.

Venter, P M 2000. Die funksie van ruimte in die reisverhale in 1 Henog 12-36. HTS $56(1), 38-62$. 